\title{
8.2 Юридична клінічна освіта як засіб формування нової методології навчання
}

Сучасна підготовка кваліфікованих правників вимагає введення в роботу професорсько-викладацького складу нових, нетрадиційних форм і методів викладання. Одним із інноваційних методів є участь у роботі юридичної клініки.

У науково-дослідній літературі переважають такі характеристики поняття «юридична клініка»:

по-перше, вона $є$ видом юридичного навчання, за якого студенти набувають практичних навичок під керівництвом викладачів через надання юридичних послуг населенню;

по-друге, вона є особливою частиною вищої юридичної освіти, що дозволяє свідомо та цілеспрямовано формувати у студентів навички професійної діяльності на основі організації такої форми навчання як керована викладачем практика надання правової допомоги малозабезпеченим особам;

по-третє, вона $є$ навчанням під час проходження практики, організованим на базі навчального закладу, у ході якого науковий, навчальний та практичний напрямки реалізуються у процесі спільної діяльності викладачів і студентів, створюючи при цьому новий вид взаємовідносин між ними, вважає Голова Правління всеукраїнської громадської організації «Асоціація юридичних клінік України» В.А. Слова.

Наведені дефініції характеризують поняття «юридична клініка» у якості соціально-орієнтованої навчальної діяльності у галузі права, яка є складовою частиною навчального процесу у вищому навчальному закладі, інноваційною (інтерактивною) методикою вироблення у студентів практичних навичок.

Найбільшим розповсюдженим розумінням юридичної клініки $\epsilon$ інституційне. У 2003-2005 pp. Асоціацією юридичних клінік України було сформовано власну внутрішню правову базу, спрямовану на забезпечення та уніфікацію діяльності юридичних клінік та їх відмежування від інших форм об'єднань студентів та молодих юристів, які надають юридичну допомогу 
населенню (прийнято Стандарти юридичних клінік України, Типове положення про юридичну клініку та Етичний кодекс діяльності юридичної клініки в Україні). Згідно з положеннями цих Стандартів, юридичні клініки могли діяти у двох організаційно-правових формах:

1) як структурний підрозділ вищого навчального закладу чи факультету, який їм підпорядковується;

2) як формування при вищому навчальному закладі чи факультеті, яке взаємодіє з ними на підставі договору та може бути юридичною особою.

Нормативно, мета діяльності юридичної клініки закріплена у Положенні про юридичну клініку «Істина» ДДУВС від 27.04.2017 № 295, під якою розуміється закріплення студентами (курсантами)- консультантами теоретичних знань та набуття ними практичних умінь і навичок професії юриста, формування в них поваги до принципів права, підвищення рівня правової культури населення, а також надання безоплатної правової допомоги особам, які іï потребують.

У монографічній літературі пропонують розрізняти три основні функції юридичної клінічної діяльності, а саме:

1) правозахисну (правової допомоги населенню);

2) просвітню (правової освіти населення);

3) навчально-формуючу (полягає у набутті студентами перших навичок практичної діяльності у сфері права, формуванні особистої громадянської позиції, моральності, соціальної відповідальності).

Вважаємо, найбільш значимою третю функцію, оскільки юридичні клініки при вищих навчальних закладах створюються перш за все для навчання студентів, а інші функції реалізуються як похідні.

Відповідно, основна мета існування юридичної клініки - освітня - набуття студентами практичних навичок у процесі надання безоплатної правничої допомоги населенню, у той час як інші напрями їхньої діяльності є вторинними (похідними). 
Саме поняття «юридична клінічна освіта» не має статусу юридичної дефініції. Перша спроба нормативно-правового закріплення поняття «юридична клінічна освіта» здійснена Міністерством освіти і науки України спільно із Міністерством юстиції України. Вони передбачали в проекті Концепції розвитку юридичної освіти поєднання навчання здобувачів вищої юридичної освіти 3 діяльністю у юридичних клініках, для чого правничі школи мають сприяти їхньому розвитку у вигляді окремих структурних підрозділів закладів вищої освіти та впровадженню в освітній процес навчальних курсів 3 правничої клінічної практики.

Найчастіше поняттям «юридична клінічна освіта» оперують у наукових дослідженнях, 3 метою характеристики унікального методу підготовки майбутніх фахівців за напрямом «Право» (з обов’язковим використанням юридичних клінік в навчальному процесі, як бази для отримання студентами додаткових теоретичних знань і практичних навичок 3 надання безоплатної правничої допомоги населенню). Зокрема, Ю.М. Савелова зазначає, що юридична клінічна освіта - це метод (методика) викладання, яка використовується в юридичних вищих навчальних закладах, у рамках якого студенти представляють інтереси реальних клієнтів (відвідувачів) під керівництвом викладачів та практикуючих юристів.

Призначення цього інтерактивного методу навчання студентів-юристів правових навичок полягає у посиленні їх практичної підготовки шляхом залучення до практичної юридичної діяльності та надання безоплатної правової допомоги малозабезпеченим верствам населення.

На противагу іншим методам підготовки правників, перевагами юридичної клінічної освіти є: отримання практичних навичок студентами до початку реальної практичної діяльності; поєднання теоретичних знань одночасно 3 отриманням практичних навичок.

Як зазначають В.С. Журавський та О.Л. Копиленко, робота молодих юристів у юридичній клініці дозволяє усвідомити цінність і значення отриманих 
теоретичних знань та оволодіти методологією та процесуальною технікою застосування цих знань на практиці.

Зміст відповідного методу підготовки майбутніх юристів полягає у створенні у самій структурі навчального закладу вищої освіти окремого навчально-практичного підрозділу, основною метою діяльності якого є набуття студентами практичних умінь і навичок з надання правничої допомоги особам 3 числа незаможних верств населення.

Організація і діяльність таких інституцій має подвійну мету: з одного боку - надання правничої допомоги людині, яка іï потребує, а з іншого - набуття студентами, які виявили бажання працювати в такій структурі на волонтерських засадах, реального первинного досвіду:

у спілкуванні з людиною, яка звернулась по допомогу;

в аналізі конкретних життєвих ситуацій і правових відносин, в які щоденно вступає людина, на підставі законодавчих та нормативно-правових актів;

консультування клієнтів; підготовки правових висновків, процесуальних документів та рекомендацій;

в окремих випадках - навіть, представництво інтересів особи перед іншими особами, органами державної влади, та місцевого самоврядування.

Юридична клініка може забезпечити безперервність практики студентів у майбутній професії. Адже специфіка роботи юридичної клініки полягає в постійному (протягом навчального року) залученні студентів до вирішення реальних справ клієнтів, які звертаються за юридичною допомогою 3 використанням усіх правових способів реалізації та захисту прав. Більшість юридичних клінік в Україні практикують не лише підготовку юридичних роз'яснень, а й складання процесуальних документів, представництво інтересів клієнтів, що становить класичну систему професійних умінь і навичок юристапрактика. Спеціалізовані юридичні клініки, крім названих видів діяльності, практикують правопросвітні заходи, тим самим надаючи своїм учасникам навички публічного виступу, користування педагогічними технологіями. 
Як засіб формування нової методології навчання, юридична клінічна освіта дозволяє впровадити в систему освіти такі принципи:

демократичний стиль відносин між викладачем і студентом (на противагу авторитарному стилю, характерному для традиційної системи освіти в цілому);

педагогіку співробітництва (студент стає рівноправним учасником освітнього процесу);

індивідуальний підхід до студента;

захист прав людини як визначальна складова професійної діяльності правника;

компоненту опанування практичних навичок, що органічно доповнює отримані у вищому навчальному закладі теоретичні знання.

Основна причина недостатнього використання юридичної клініки, як основної платформи набуття практичних навичок студентами, пов'язане 3 нормативною неврегульованістю такої можливості. Подолати дану прогалину, хоча б частково, допоможе прийняття проекту Концепції розвитку юридичної освіти від 28 лютого 2020 року, у якій передбачено сприяння розвитку юридичних клінік у вигляді окремих структурних підрозділів закладів вищої освіти та впровадження в освітній процес навчальних курсів 3 юридичної клінічної практики, а одним з індикаторів досягнення є збільшення відсотка залучення здобувачів освіти до участі в юридичних клініках, кількості активно функціонуючих юридичних клінік.

3 метою легалізації поняття «юридична клінічна освіта» та набуття останнім офіційного статусу - юридичної дефініції, вважаємо за необхідне:

1. Прийняти у цілому проект «Концепції розвитку юридичної освіти», розроблений Міністерством освіти і науки України спільно із Міністерством юстиції України.

2. Встановити у нормативно-правових актах 3 організації навчального процесу, проведення навчальної практики та обліку часу роботи науковопедагогічних працівників приписи щодо необхідності безпосереднього упровадження положень про діяльність юридичних клінік; 
3. Закріпити на рівні зобов'язуючої норми права приписи щодо необхідності функціонування юридичної клініки, як умови акредитації юридичного закладу вищої освіти та отримання ним ліцензії на підготовку юристів;

4. Нормативно передбачити систему громадського контролю за якістю функціонування юридичних клінік у структурі юридичного закладу вищої освіти. 